\title{
Union Membership and Employment Dynamics: A Note
}

\author{
Marcus Dittrich \\ Beate Schirwitz
}

CESIFO WORKING PAPER No. 3173

CATEGORY 4: LABOUR MARKETS

SEPTEMBER 2010
An electronic version of the paper may be downloaded
- from the SSRN website:
- from the RePEc website:
- from the CESifo website:
www.SSRN.com
Www.RePEc.org
www.CESifo-group.org/wp




\title{
Union Membership and Employment Dynamics: A Note
}

\begin{abstract}
We analyze union behavior in a model with membership dynamics and compare the labor market outcomes to static union models. Based on empirical findings we modify standard models and show that the well-known result that static models overstate distortions caused by unions only holds in the special case of firm-level wage setting. If, however, the union is big enough to determine employment for the whole sector, it rather depends on both the elasticity of labor demand and union's time preference whether static frameworks overrate or even underrate unions' distortions.
\end{abstract}

JEL-Code: C61, J50, J51.

Keywords: unions, endogenous membership, bargaining centralization.

\author{
Marcus Dittrich \\ Chemnitz University of Technology \\ Faculty of Economics and Business \\ Administration \\ Strasse der Nationen 62 \\ Germany - 09107 Chemnitz \\ marcus.dittrich@wirtschaft.tu-chemnitz.de
}

\author{
Beate Schirwitz \\ Ifo Institute for Economic Research \\ Dresden Branch \\ Einsteinstraße 3 \\ Germany - 01069 Dresden \\ schirwitz@ifo.de
}

June 14, 2010 


\section{Introduction}

The seminal work on intertemporal union behavior by Jones (1987) and Kidd \& Oswald (1987) (henceforth JKO) states that conventional static models overrate the distortions caused by unionism. This result stems from the assumption that unemployed workers leave their union, which makes that union membership depends on employment. Therefore, a union faces an intertemporal optimization problem and needs to balance the gains from higher wages not only against immediate lower employment but also against the resulting shrinkage of the union. Hence, in comparison with static models, the union has an extra incentive to keep up employment.

Considering membership dynamics is important to better understand intertemporal union behavior. JKO implicitly make two nontrivial assumptions, though. First, wage setting takes place at the firm level. This assumption implies a large number of small unions each of which has a negligible impact on the workers' outside option. Second, JKO assume that all unemployed workers immediately leave the union after losing their jobs in the unionized sector.

These assumptions, however, do not necessarily meet the empirical facts. It is well-known that OECD countries differ in their degree of bargaining centralization. While there is decentralized bargaining at the firm level in Canada, Japan, the United States, and the United Kingdom, we find centralized wage setting e.g. in Austria, Denmark, and Norway (OECD 2004). Moreover, there is an intermediate form of wage bargaining at the branch level that is typical for some continental European countries. The macroeconomic importance of differing degrees of bargaining centralization was first highlighted by Calmfors \& Driffill (1988). They postulate that the stage at which wage setting takes place is crucial for the labor market outcome of union-firm negotiations. The second assumption rests upon observations that changes in union membership move with changes in unemployment (Booth 1983, Carruth \& Disney 1988). However, recent empirical evidence shows that a significant fraction of workers stay in the union even after having lost their union jobs. In countries like Belgium, Denmark, Finland or Sweden, e.g., $80 \%$ of the unemployed keep organized in unions (Visser 2006). This paper expands the JKO framework to meet these empirical facts. We construct a general model where we analyze both decentralized and centralized union behavior. In this latter scenario, a large centralized union takes into account that employment decisions in the unionized sector directly influence the workers' out- 
side option. Furthermore, we assume that only a fraction of those workers who lose their jobs in the unionized sector quit union membership.

Employing these extensions, we find that the results of JKO are not universally valid. They only apply unconditionally if wage setting takes place decentralized at the firm level. In an economy with centralized wage setting, however, static models may even underrate distortions caused by unions. We show that the employment effects then depend on both the elasticity of labor demand and the union's time preference rate.

\section{The model}

\section{Firms and unions}

We consider an economy with a unionized and a competitive sector. There are $\gamma$ identical union-firm pairs in the unionized sector. The number of firms in the competitive sector is normalized to unity. The economy is inhabited by $z$ identical, risk-neutral workers, each of them inelastically supplying one unit of labor. For each period $t$, the number of workers in a union-firm is given by $n_{t}$. Workers who are not employed in the unionized sector move to the competitive sector operating as residual labor market. The respective production functions of a representative firm in the unionized and the competitive sector are given by $f^{u}\left(n_{t}\right)=n_{t}^{\alpha}$ and $f^{c}\left(z-\gamma n_{t}\right)=\left[z-\gamma n_{t}\right]^{\beta}$, with $\alpha, \beta \in(0,1)$ representing constant elasticities. The exogenous output price is normalized to one. Firms' profit maximizing labor demand in the unionized sector follows from the marginal productivity condition

$$
w_{t}=\alpha n_{t}^{\alpha-1}
$$

Since labor supply in the competitive sector is given by the residual workers not employed in any unionized firm, the competitive wage $b_{t}$ adjusts such that

$$
b_{t}=\beta\left[z-\gamma n_{t}\right]^{\beta-1}
$$

We employ the dynamic formulation of the standard monopoly union model (McDonald \& Solow 1981) proposed by JKO. Utilitarian unions maximize the wage sum of their members. With $m_{t}$ denoting membership, union's utility in $t$ is 
described by

$$
u_{t}=n_{t}\left[w_{t}-b_{t}\right]+m_{t} b_{t}
$$

In accordance with JKO, a union does not only care about current but also about future utility. Union's objective function is hence the intertemporal notation of (3):

$$
v=\int_{0}^{\infty} u_{t} e^{-r t} d t
$$

with $r$ representing the time preference rate.

Given the assumptions of $\gamma$ identical firms and unions and $z$ as the total number of workers in the economy, $\tilde{m} \equiv \frac{z}{\gamma}$ denotes the exogenous potential labor force in each union-firm. Hence, $\tilde{m}$ represents the maximum number of a single union's members. To meet the empirical facts discussed above, we consider that some of the workers not employed in the unionized sector quit their membership, i. e. $m_{t} \leq \tilde{m}$. However, while JKO assume that all these workers leave the union, we instead suggest that only a fraction of them quit their membership. In particular, we denote the fraction of workers that stick to the union even if losing their jobs in the unionized sector with $\sigma \in[0,1) .{ }^{1}$ Accordingly, the evolution in union membership over time is described as

$$
m_{t}=n_{t-1}+\sigma\left[\tilde{m}-n_{t-1}\right]
$$

That is, union membership in $t$ results from previous period's number of employed workers in the unionized sector $\left(n_{t-1}\right)$ plus a fraction $\sigma$ of the remaining workers $\left(\tilde{m}-n_{t-1}\right)$ in the competitive sector. Following JKO, with transition to continuous time membership dynamics becomes

$$
\dot{m}=[1-\sigma] n-m+\sigma \tilde{m},
$$

where the time index is suppressed for notational reasons.

\footnotetext{
${ }^{1}$ To keep the analysis simple we assume $\sigma$ to be exogenous. Endogenizing union density, as proposed by Chang \& Lai (1997), would not change our results qualitatively.
} 


\section{Employment determination}

Monopoly unions set the wage or employment in the unionized sector considering the firms' marginal productivity condition (1), i. e. wage and employment determination are interchangeable. For ease of comparison with JKO, we set up the model in terms of employment. We develop a general framework from which we can derive two different scenarios: First, following JKO, employment determination takes place at the firm level. As there are many union-firm pairs in the unionized sector, each small union neglects the consequences of its decision on wage and employment in the competitive sector. Second, taking into account the empirical evidence for a sizeable number of countries, we consider centralized employment determination for the whole unionized sector. In this case, one large union represents all $\gamma$ firm-unions. This union explicitly takes into account that setting a lower employment level in the unionized sector increases labor supply in the competitive sector which decreases the competitive wage and therefore lowers its remaining members' outside option.

Accordingly, both scenarios differ in two respects: (i) the number of firm-unions included, and (ii) the considered functional relationship between employment in the unionized sector and the wage in the competitive sector. Hence, we formulate the union's general maximization problem:

$$
\begin{array}{cl}
\max _{n} & \int_{0}^{\infty} \varphi_{i}\left[n\left[w-b_{i}(n)\right]+m b_{i}(n)\right] e^{-r t} d t \\
\text { s.t. } & w=\alpha n^{\alpha-1} \\
& \dot{m}=[1-\sigma] n-m+\sigma \tilde{m},
\end{array}
$$

where $i=\{d, c\}$ denotes the decentralized and the centralized case, respectively. The different number of unions in (7) is captured by

$$
\varphi_{i}=\left\{\begin{array}{lll}
1 & \text { if } & i=d \\
\gamma & \text { if } & i=c
\end{array}\right.
$$

The second difference between decentralized and centralized unions rests upon their considered influence on the competitive sector. In particular, in the decentralized case each firm-union takes the competitive wage as given. ${ }^{2}$ The cen-

\footnotetext{
${ }^{2}$ While the competitive wage is constant from each small union's viewpoint, it is of course endogenously determined in equilibrium.
} 
tralized union, however, explicitly considers the relationship between wages and employment in both sectors expressed by (2). Hence the centralized union faces an additional constraint in the optimization problem:

$$
b_{i}(n)= \begin{cases}\bar{b} & \text { if } \quad i=d \\ \beta[z-\gamma n]^{\beta-1} & \text { if } \quad i=c .\end{cases}
$$

Let $\lambda$ be the co-state variable. The present value Hamiltonian for (7) is given by

$$
\mathcal{H}=\varphi_{i}\left[n\left[\alpha n^{\alpha-1}-b_{i}(n)\right]+m b_{i}(n)\right] e^{-r t}+\lambda[[1-\sigma] n-m+\sigma \tilde{m}]
$$

and the first order conditions include

$$
\begin{aligned}
\mathcal{H}_{n} & =\varphi_{i}\left[\alpha^{2} n^{\alpha-1}-b_{i}(n)+[m-n] b_{i}^{\prime}(n)\right] e^{-r t}+\lambda[1-\sigma]=0 \\
\mathcal{H}_{m} & =\varphi_{i} b_{i}(n) e^{-r t}-\lambda=-\dot{\lambda}
\end{aligned}
$$

Using (9) to eliminate $\lambda$ and $\dot{\lambda}$ in (10), the time path for employment is given by

$$
\dot{n}_{i}=\frac{1+r}{\delta}\left[\alpha^{2} n^{\alpha-1}-\frac{\sigma+r}{1+r} b_{i}(n)+[m-n] b_{i}^{\prime}(n)\right]
$$

with $\delta=\alpha^{2}[\alpha-1] n^{\alpha-2}-2 b_{i}^{\prime}(n)+[m-n] b_{i}^{\prime \prime}(n)$. In the steady state, $\dot{n}=0$ holds. The corresponding equilibrium employment is therefore implicitly represented by

$$
n_{i}=\left[\frac{\sigma+r}{1+r} \frac{b_{i}(n)}{\alpha^{2}}-\frac{\left(m_{i}-n_{i}\right) b_{i}^{\prime}\left(n_{i}\right)}{\alpha^{2}}\right]^{\frac{1}{\alpha-1}} .
$$

We can now derive equilibrium employment with decentralized unions as a special case of (12). Considering $b_{d}^{\prime}(n)=0$ from each union's viewpoint if employment is determined on the firm level, we end up in a result very similar to JKO:

$$
n_{d}=\left[\frac{\sigma+r}{1+r} \frac{b_{d}}{\alpha^{2}}\right]^{\frac{1}{\alpha-1}} .
$$

The equivalent static solution, which can be derived by maximizing (3) and ignoring membership dynamics, is given by $n_{d}^{\text {stat }}=\left[\frac{b_{d}^{\text {stat }}}{\alpha^{2}}\right]^{\frac{1}{\alpha-1}}$. Compared to (13), where the mark-up $\frac{\sigma+r}{1+r}<1$ applies, it is easy to see that employment is higher in the dynamic case. Hence, with decentralized unions JKO's finding that static models overrate the distortions caused by unionism also holds in our more general 
case with $0 \leq \sigma<1$.

Analyzing a centralized union representing all firm-unions, however, we have to take into account the competitive wage as a function of unionized employment. A change in this wage due to a change in unionized employment is expressed by the derivative of $(2)$ :

$$
b_{c}^{\prime}(n)=\gamma \beta[1-\beta][z-\gamma n]^{\beta-2}>0 .
$$

Since in long-run equilibrium also $\dot{m}=0$ holds, we find from (6) that $m-n=$

$\sigma[\tilde{m}-n]$. Inserting into (12) and using $\tilde{m} \equiv \frac{z}{\gamma}$ together with (14) allows to calculate employment set by a centralized union:

$$
n_{c}=\left[\left[\frac{\sigma+r}{1+r}+\sigma[\beta-1]\right] \frac{b_{c}}{\alpha^{2}}\right]^{\frac{1}{\alpha-1}} \text {. }
$$

Because of the additional mark-up $\sigma[\beta-1]<0$, comparing (15) with (13) reveals that employment is higher with a centralized union than with firm-level unions. A second, more important result is found comparing static and dynamic optimization results. While JKO clearly state that (decentralized) unions maximizing an intertemporal utility function set higher employment, we find that centralized employment setting yields ambiguous results. Dittrich (2008) shows that a central union's static utility maximization yields $n_{c}^{\text {stat }}=\left[\beta \frac{b_{c}^{\text {stat }}}{\alpha^{2}}\right]^{\frac{1}{\alpha-1}}$. Comparing with (15) shows that intertemporal union behavior yields higher employment only if

$$
\beta>\frac{r}{1+r} .
$$

Hence, if the measure of the labor demand elasticity $\beta$ is low enough compared to the union's time preference rate $r$, conventional static models may even underrate the distortions caused by unions.

\section{Discussion of the results}

Finally, we want to briefly comment on the basic intuition behind our main results. For ease of comparison, Table 1 summarizes the respective mark-ups using employment set by a decentralized union in the static case, $n_{d}^{\text {stat }}=\left[\frac{b}{\alpha^{2}}\right]^{\frac{1}{\alpha-1}}$, as benchmark.

The first and most obvious result is that employment is higher in the dynamic 


\begin{tabular}{lll}
\hline & Static & Dynamic \\
\hline Decentralized & 1 & {$\left[\frac{\sigma+r}{1+r}\right]^{\frac{1}{\alpha-1}}$} \\
Centralized & $\beta^{\frac{1}{\alpha-1}}$ & {$\left[\frac{\sigma+r}{1+r}+\sigma[\beta-1]\right]^{\frac{1}{\alpha-1}}$} \\
\hline
\end{tabular}

Table 1: Employment mark-ups compared to benchmark.

than in the static scenario if there are decentralized unions. This result is driven by the "intertemporal" mark-up $\frac{\sigma+r}{1+r}<1$, if unions consider membership dynamics. As (13) shows, unionized employment is the higher the lower the time preference rate $r$, i. e. the more painful future membership losses are considered. The static framework, on the contrary, might be represented by $r \mapsto \infty$. Therefore, (13) replicates the result derived by JKO that static models overstate the distortions caused by unions.

However, the picture is less clear for a centralized union which takes the effect on its members' outside option into account. The union's influence on the competitive wage depends on the elasticity of labor demand there which is determined by $\beta$. If $\beta$ is small, i.e. if labor demand in the competitive sector is rather inelastic, a relatively small decrease in competitive employment, induced by a small increase in unionized employment, yields a relatively large increase in the competitive wage. Since a union in the static framework takes this effect into account, there is an incentive to set a higher employment level the lower is $\beta$. As seen in Table $1, \beta$ represents the static "centralization" mark-up.

In the dynamic scenario, employment is driven by both the intertemporal as well as a centralization mark-up. The intertemporal mark-up $\frac{\sigma+r}{1+r}$ is the same as in the decentralized framework: the more the union values future losses in membership, the more it is willing to prevent these losses by setting higher employment. The centralization mark-up $\sigma[\beta-1]$, however, differs from the static case since it now depends on the fraction of workers leaving the union. In general it holds that the more workers leave the union, the less the union cares about the competitive sector. Hence, for any given $\sigma<1$, the centralization mark-up is less effective in the dynamic than in the static scenario.

A consolidated view indicates that, on the one hand, the intertemporal markup results in higher employment in the dynamic framework. The lower $r$, the higher is employment set by the union. On the other hand, the centralization mark-up is more effective in the static framework. Hence, unionized employment 
will already be rather high, depending on $\beta$, in the static framework. Obviously, if there is centralized employment setting, a static model overstates distortions caused by unionism only if $\beta$ is large and/or $r$ is low enough. Otherwise, if $r$ is high enough, the union's loss from membership quits takes place in the less valued future. Today's wage gain in the union sector resulting from lower employment might then be higher. Altogether, the main reason why the findings of JKO do not unconditionally apply in a centralized framework stems from the different centralization mark-ups in the static and the intertemporal framework.

\section{Conclusion}

The note provides some new insights in the discussion on labor market distortions caused by unionism. Adjusting the JKO framework to better meet empirical evidence, we show that their findings might also hold if only a part of workers that lose their jobs leave the union. However, this is unconditionally valid only if employment determination takes place at the firm level. Otherwise, in an economy with centralized employment setting, static models may even understate distortions caused by unions. The employment effects there depend on the relationship between the elasticity of labor demand and the time preference rate.

\section{References}

Booth, A. L. (1983), 'A reconsideration of trade union growth in the United Kingdom', British Journal of Industrial Relations 21(3), 379-393.

Calmfors, L. \& Driffill, J. (1988), 'Bargaining structure, corporatism and macroeconomic performance', Economic Policy 3(6), 13-61.

Carruth, A. A. \& Disney, R. F. (1988), 'Where have two million trade union members gone?', Economica 55(217), 1-19.

Chang, J.-J. \& Lai, C.-C. (1997), 'Union membership and employment dynamics with endogenous union density', Economics Letters 57(1), 119-125.

Dittrich, M. (2008), 'Union wage setting in a dual labour market: The role of centralisation', International Economic Journal 22(4), 461-470. 
Jones, S. R. G. (1987), 'Union membership and employment dynamics', Economics Letters 25(2), 197-200.

Kidd, D. P. \& Oswald, A. J. (1987), 'A dynamic model of trade union behaviour', Economica 54(215), 355-365.

McDonald, I. M. \& Solow, R. M. (1981), 'Wage bargaining and employment', American Economic Review 71(5), 896-908.

OECD (2004), Employment Outlook, OECD, Paris.

Visser, J. (2006), 'Union membership statistics in 24 countries', Monthly Labor Review 129(1), 38-49. 


\section{CESifo Working Paper Series}

for full list see www.cesifo-group.org/wp

(address: Poschingerstr. 5, 81679 Munich, Germany, office@cesifo.de)

3111 Johannes Metzler and Ludger Woessmann, The Impact of Teacher Subject Knowledge on Student Achievement: Evidence from Within-Teacher Within-Student Variation, June 2010

3112 Leif Danziger, Uniform and Nonuniform Staggering of Wage Contracts, July 2010

3113 Wolfgang Buchholz and Wolfgang Peters, Equity as a Prerequisite for Stable Cooperation in a Public-Good Economy - The Core Revisited, July 2010

3114 Panu Poutvaara and Olli Ropponen, School Shootings and Student Performance, July 2010

3115 John Beirne, Guglielmo Maria Caporale and Nicola Spagnolo, Liquidity Risk, Credit Risk and the Overnight Interest Rate Spread: A Stochastic Volatility Modelling Approach, July 2010

3116 M. Hashem Pesaran, Predictability of Asset Returns and the Efficient Market Hypothesis, July 2010

3117 Dorothee Crayen, Christa Hainz and Christiane Ströh de Martínez, Remittances, Banking Status and the Usage of Insurance Schemes, July 2010

3118 Eric O’N. Fisher, Heckscher-Ohlin Theory when Countries have Different Technologies, July 2010

3119 Huw Dixon and Hervé Le Bihan, Generalized Taylor and Generalized Calvo Price and Wage-Setting: Micro Evidence with Macro Implications, July 2010

3120 Laszlo Goerke and Markus Pannenberg, 'Take it or Go to Court' - The Impact of Sec. 1a of the German Protection against Dismissal Act on Severance Payments -, July 2010

3121 Robert S. Chirinko and Daniel J. Wilson, Can Lower Tax Rates be Bought? Business Rent-Seeking and Tax Competition among U.S. States, July 2010

3122 Douglas Gollin and Christian Zimmermann, Global Climate Change and the Resurgence of Tropical Disease: An Economic Approach, July 2010

3123 Francesco Daveri and Maria Laura Parisi, Experience, Innovation and Productivity Empirical Evidence from Italy's Slowdown, July 2010

3124 Carlo V. Fiorio and Massimo Florio, A Fair Price for Energy? Ownership versus Market Opening in the EU15, July 2010

3125 Frederick van der Ploeg, Natural Resources: Curse or Blessing?, July 2010 
3126 Kaisa Kotakorpi and Panu Poutvaara, Pay for Politicians and Candidate Selection: An Empirical Analysis, July 2010

3127 Jun-ichi Itaya, Makoto Okamura and Chikara Yamaguchi, Partial Tax Coordination in a Repeated Game Setting, July 2010

3128 Volker Meier and Helmut Rainer, On the Optimality of Joint Taxation for NonCooperative Couples, July 2010

3129 Ryan Oprea, Keith Henwood and Daniel Friedman, Separating the Hawks from the Doves: Evidence from Continuous Time Laboratory Games, July 2010

3130 Mari Rege and Ingeborg F. Solli, The Impact of Paternity Leave on Long-term Father Involvement, July 2010

3131 Olaf Posch, Risk Premia in General Equilibrium, July 2010

3132 John Komlos and Marek Brabec, The Trend of BMI Values by Centiles of US Adults, Birth Cohorts 1882-1986, July 2010

3133 Emin Karagözoğlu and Arno Riedl, Information, Uncertainty, and Subjective Entitlements in Bargaining, July 2010

3134 John Boyd, Gianni De Nicolò and Elena Loukoianova, Banking Crises and Crisis Dating: Theory and Evidence, July 2010

3135 Michael R. Baye, Dan Kovenock and Casper G. de Vries, The Herodotus Paradox, July 2010

3136 Martin Kolmar and Hendrik Rommeswinkel, Group Contests with Complementarities in Efforts, July 2010

3137 Carolina Manzano and Xavier Vives, Public and Private Learning from Prices, Strategic Substitutability and Complementarity, and Equilibrium Multiplicity, July 2010

3138 Axel Löffler, Gunther Schnabl and Franziska Schobert, Inflation Targeting by Debtor Central Banks in Emerging Market Economies, July 2010

3139 Yu-Fu Chen and Michael Funke, Global Warming and Extreme Events: Rethinking the Timing and Intensity of Environmental Policy, July 2010

3140 Lawrence M. Kahn, Labor Market Policy: A Comparative View on the Costs and Benefits of Labor Market Flexibility, July 2010

3141 Ben J. Heijdra, Jochen O. Mierau and Laurie S.M. Reijnders, The Tragedy of Annuitization, July 2010

3142 Erkki Koskela, Outsourcing Cost and Tax Progression under Nash Wage Bargaining with Flexible Outsourcing, July 2010 
3143 Daniel Osberghaus and Christiane Reif, Total Costs and Budgetary Effects of Adaptation to Climate Change: An Assessment for the European Union, August 2010

3144 Philip E. Graves, Benefit-Cost Analysis of Environmental Projects: A Plethora of Systematic Biases, August 2010

3145 Sabrina Di Addario and Daniela Vuri, Entrepreneurship and Market Size. The Case of Young College Graduates in Italy, August 2010

3146 Shoshana Amyra Grossbard and Alfredo Marvăo Pereira, Will Women Save more than Men? A Theoretical Model of Savings and Marriage, August 2010

3147 Jarko Fidrmuc, Time-Varying Exchange Rate Basket in China from 2005 to 2009, August 2010

3148 Ilja Neustadt and Peter Zweifel, Is the Welfare State Sustainable? Experimental Evidence on Citizens' Preferences for Redistribution, August 2010

3149 Marcus Dittrich and Andreas Knabe, Wage and Employment Effects of Non-Binding Minimum Wages, August 2010

3150 Shutao Cao, Enchuan Shao and Pedro Silos, Fixed-Term and Permanent Employment Contracts: Theory and Evidence, August 2010

3151 Ludger Woessmann, Cross-Country Evidence on Teacher Performance Pay, August 2010

3152 Lorenzo C. G. Pozzi, Casper G. de Vries and Jorn Zenhorst, World Equity Premium Based Risk Aversion Estimates, August 2010

3153 Volker Grossmann, Thomas M. Steger and Timo Trimborn, Dynamically Optimal R\&D Subsidization, August 2010

3154 Alexander Haupt, Tim Krieger and Thomas Lange, A Note on Brain Gain and Brain Drain: Permanent Migration and Education Policy, August 2010

3155 António Afonso and Christophe Rault, Long-run Determinants of Sovereign Yields, August 2010

3156 Franziska Tausch, Jan Potters and Arno Riedl, Preferences for Redistribution and Pensions. What can we Learn from Experiments?, August 2010

3157 Martin Kolmar and Andreas Wagener, Inefficient Group Organization as Optimal Adaption to Dominant Environments, August 2010

3158 Kai Carstensen, Klaus Wohlrabe and Christina Ziegler, Predictive Ability of Business Cycle Indicators under Test: A Case Study for the Euro Area Industrial Production, August 2010 
3159 Horst Rottmann and Timo Wollmershäuser, A Micro Data Approach to the Identification of Credit Crunches, August 2010

3160 Philip E. Graves, Appropriate Fiscal Policy over the Business Cycle: Proper Stimulus Policies Can Work, August 2010

3161 Michael Binder and Marcel Bluhm, On the Conditional Effects of IMF Program Participation on Output Growth, August 2010

3162 Michael Binder, Qianying Chen, and Xuan Zhang, On the Effects of Monetary Policy Shocks on Exchange Rates, August 2010

3163 Felix J. Bierbrauer, On the Optimality of Optimal Income Taxation, August 2010

3164 Nikolaus Wolf, Europe's Great Depression - Coordination Failure after the First World War, September 2010

3165 Dan Kovenock and Brian Roberson, Conflicts with Multiple Battlefields, September 2010

3166 Jean-Pierre Ponssard and Catherine Thomas, Capacity Investment under Demand Uncertainty. An Empirical Study of the US Cement Industry, 1994-2006, September 2010

3167 Jørgen Juel Andersen, Jon H. Fiva and Gisle James Natvik, Voting when the Stakes are High, September 2010

3168 Michael Hoel, Is there a Green Paradox?, September 2010

3169 Scott Alan Carson, Nineteenth Century US African-American and White Female Statures: Insight from US Prison Records, September 2010

3170 Gil S. Epstein, Yosef Mealem and Shmuel Nitzan, Political Culture and Discrimination in Contests, September 2010

3171 Sara Fisher Ellison, Jeffrey Greenbaum and Wallace P. Mullin, Diversity, Social Goods Provision, and Performance in the Firm, September 2010

3172 Silvia Dominguez-Martinez, Randolph Sloof and Ferdinand von Siemens, Monitoring your Friends, not your Foes: Strategic Ignorance and the Delegation of Real Authority, September 2010

3173 Marcus Dittrich and Beate Schirwitz, Union Membership and Employment Dynamics: A Note, September 2010 